\title{
Pengembangan Desa Wisata Taro berbasis digital marketing sosial media
}

\author{
Ni Made Anggia Paramesthi Fajar ${ }^{1 *}$, I Wayan Diasa ${ }^{2}$, Ade Maharini Adiandari ${ }^{3}$ \\ ${ }^{1}$ Fakultas Hukum Universitas Ngurah Rai, Jalan Padma, Penatih, Denpasar, Indonesia \\ ${ }^{2}$ Fakultas Sains dan Teknologi, Jalan Padma, Penatih, Denpasar, Indonesia \\ ${ }^{3}$ Fakultas Ekonomi dan Bisnis Universitas Ngurah Rai, Jalan Padma, Penatih, Denpasar, \\ Indonesia
}

*) Korespondensi (e-mail: anggiaparamesti@gmail.com)

Received: 17-December-21; Revised: 22- December -21; Accepted: 23- December -21

\begin{abstract}
Taro Village is one of the tourism villages that has the oldest history in Bali. This Taro Tourism Village is an old village in Bali that is rich in stories and cultural relics of the past. The existence of this village is closely related to the visit of a sacred person in the past from East Java to Bali around the 8th century. This Taro Tourism Village has green and beautiful nature. The cool air and the trees make the atmosphere shady. As well as residents' houses with the characteristics of traditional Balinese houses. Besides enjoying the natural atmosphere, the tourist village of Taro also has many cultural values that can be an interesting source of knowledge for visitors to the tourist village. However, along with the development of the times, the Taro Tourism Village began to experience a setback because of the many other tourist attractions that offered new "experiences" for tourists. so it requires the need for new packaging of tourism activities while still using religious culture and beautiful nature as the main components.
\end{abstract}

Keywords: Taro Tourism Village, Culture, Religion

\begin{abstract}
Abstrak
Desa Taro adalah salah satu Desa Wisata yang memiliki sejarah tertua di Bali. Desa Wisata Taro ini merupakan desa tua di Bali yang kaya akan kisah dan peninggalan budaya masa lampau. Keberadaan desa ini berkaitan erat dengan lawatan seorang yang sakti di masa lalu dari Jawa Timur ke Bali sekitar abad ke 8. Desa Wisata Taro ini memiliki alam yang hijau dan asri. Udara yang sejuk serta pepohonan membuat suasana menjadi rindang. Serta rumah penduduk dengan ciri khas rumah tradisional Bali. Selain menikmati suasana alam, desa wisata taro juga banyak memiliki nilai kebudayaan yang dapat menjadi sumber pengetahuan yang menarik bagi para pengunjung desa wisata tersebut. namun seiring perkembangan zaman Desa Wisata Taro mulai mengalami kemunduran karena banyaknya objek wisata lain yang menawarkan "pengalaman" baru bagi para wisatawan. sehingga membutuhkan perlu adanya pengemasan baru dari kegiatan pariwisata dengan tetap menggunakan budaya religious dan alam yang asri sebagai komponen utama.
\end{abstract}

Kata kunci: Desa Wisata taro, Budaya, Religius

How to cite: Fajar, N. M. A. P. ., Diasa, I. W., \& Adiandari, A. M. (2021). Pengembangan Desa Wisata Taro berbasis digital marketing sosial media. Penamas: Journal of Community Service, 1(2), 116-124. https://doi.org/10.53088/penamas.v1i2.241 


\section{Pendahuluan}

Bali dikenal sebagai destinasi pariwisata dengan hampir seluruh objek wisatanya menawarkan kebudayaan dengan ciri khas masing-masing. salah satu desa tertua di bali yang juga menawarkan pesona potensi pariwisata budaya yang kuat adalah desa Taro. Desa Taro adalah salah satu desa tua yang ada di Kabupaten Gianyar, provinsi Bali. Berbagai cerita sejarah dan kearifan local masih terpelihara dengan baik di Desa Taro termasuk upaya untuk menjaga dan melestarikan satwa dan alamnya. Termasuk cara bercocok tanam (Subak) dan keseharian masyarakat yang memegang teguh nilai budaya dan adatnya masih sangat kental sekali (Wijaya et al., 2021). Sehingga spirit untuk mengembangkan Desa Taro menjadi Desa Wisata sangatlah menunjang dari sisi alam, budaya dan sumber daya manusianya. Keunikan sejarah, keragaman budaya serta pesona alam Desa Taro sudah merupakan modal besar untuk pengembangan Desa Wisata yang berbasis kelestarian alam dan kearifan local (spiritualitas)(Purnawan \& Sardiana, 2018; Shobah et al., 2019). Sehingga pengembangannya haruslah melibatkan seluruh elemen masyarakat Desa Taro tidak saja sebagi objek wisata, melainkan berperan besar sebagai subjek pariwisata.

Pariwisata merupakan subjek pendapatan yang memiliki potensi besar untuk Desa Taro, jika dapat dikelola dengan baik. Melihat prospek kepariwisataan inilah, sudah seharusnya pengembangan Desa Taro sebagai desa wisata yang bersifat religious dengan daya tariknya tersendiri dapat dikembangkan secara lebih intensif, yakni dengan mempersiapkan dan memperbaiki kualitas objek dan atraksi yang ada dengan tetap menggali potensi wisata yang dimiliki, melakukan perencanaan, dan pengelolaan pembangunan objek wisata yang lebih baik, sehingga mendapatkan hasil yang lebih maksimal. pengembangan dan pengelolaan objek wisata tidak hanya dapat dilakukan oleh satu pihak saja, namun harus adanya sinergitas antara pemangku kebijakan dan juga peran serta aktif masyarakat dalam pengembangan desa wisata. selain itu untuk dapat memaksimalkan fungsi desa wisata dengan penguatan sumber daya manusia dari Desa Taro sendiri merupakan hal yang sangat penting untuk diperhatikan. sehingga keberadaan desa wisata jga dapat memberikan manfaat yang maksimal bagi masyarakat di desa taro (Sutiani, 2022; Wijaya et al., 2021).

Pemetaan potensi desa sebagai salah satu sumber penghasilan desa sangat penting dilakukan untuk kemajuan desa yang mandiri dan berkelanjutan (Sumerta \& Rai, 2021) . Desa wisata Taro menawarkan pengalaman baru, hidup menyatu dengan alam pedesaan yang masih asri dan juga memiliki nilai budaya dan religi yang kuat , menghirup udara segar, jauh dari polusi dan kebisingan, merasakan dan terlibat dalam aktivitas masyarakat setempat, dalam artian bahwa wisatawan tidak hanya melihat begitu saja keindahan alam, tetapi dapat hidup di dalamnya. Wisatawan dapat merasakan dan menikmati secara utuh alam dan sosial budaya di desa taro. Pengembangan desa wisata merupakan salah satu usaha untuk mengantisipasi bahwa orientasi pilihan wisatawan pada tempat-tempat wisata yang tidak "alami" dan juga "asli" akan mencapai titik jenuh. Cara menggali, memanfaatkan, dan membangun sumber daya lokal yang selama ini kurang mendapat perhatian, serta untuk 
meningkatkan pendapatan berganda masyarakat desa setempat, serta untuk menyeleksi segmen pasar wisatawan yang berorientasi pada budaya dan peduli lingkungan, sesuai dengan amanat pelaksanaan kegiatan kepariwisataan di provinsi bali yaitu pariwisata budaya yang berkesinambungan. Dengan berbagai potensi yang dimilii oleh desa taro tersebut namun masih banyak wisatawa yang belum mengenal berbagai objek wisata yang ada di dalam desa taro sendiri, hal ini dikarenakan oleh SDM yang kurang berpengalaman dalam pemasaran desa wisata itu sendiri , perkembangan zaman ke era digitalisasi membuat desa wisata taro mengalami kemunduran di aspek digital marketing, padahal dimasa sekarang masyarakat lebih banyak menghabiskan waktunya di social media.

Perkembangan teknologi menuntut setiap bidang usaha untuk berinovasi dalam melakukan pemasaran produk guna memberikan kepuasan bagi konsumen serta mempelajari segala perilaku konsumen dalam bermedia online (Sumerta, Widyagoca, \& Meryawan, 2019). Masyarakat saat ini sanget cenderung mudah menggunakan produk-produk yang berbasis teknologi atau yang dipasarkan melakui pemanfaatan teknologi (Sumerta, Widyagoca, Adiandari, et al., 2019). Untuk itu pemasaran berbasis digital marketing untuk memperkenalkan potensi desa wisata dan destinasi - destinasi yang dimiliki oleh Desa taro harus terus dikembangkan. Pemanfaatan digital dalam transformasi pemasaran desa wisata berbasis kerakyatan di bali sangatlah penting guna mendukung peningkatan kunjungan wisatawan untuk menikmati destinasi yang ditawarkan (Nirmala \& Lavianto, 2019; Sudirgayasa et al., 2021).

\section{Analisis Situasi}

Desa Taro adalah salah satu desa tua yang ada di Kabupaten Gianyar, provinsi Bali. Berbagai cerita sejarah dan kearifan local masih terpelihara dengan baik di Desa Taro termasuk upaya untuk menjaga dan melestarikan satwa dan alamnya. Termasuk cara bercocok tanam (Subak) dan keseharian masyarakat yang memegang teguh nilai budaya dan adatnya masih sangat kental sekali. Sehingga spirit untuk mengembangkan Desa Taro menjadi Desa Wisata sangatlah menunjang dari sisi alam, budaya dan sumber daya manusianya. Keunikan sejarah, keragaman budaya serta pesona alam Desa Taro sudah merupakan modal besar untuk pengembangan Desa Wisata yang berbasis kelestarian alam dan kearifan local (spiritualitas). Sehingga pengembangannya haruslah melibatkan seluruh elemen masyarakat Desa Taro tidak saja sebagi objek wisata, melainkan berperan besar sebagai subjek pariwisata.

Pariwisata merupakan subjek pendapatan yang memiliki potensi besar untuk Desa Taro, jika dapat dikelola dengan baik. Melihat prospek kepariwisataan inilah, sudah seharusnya pengembangan Desa Taro sebagai desa wisata yang bersifat religious dengan daya tariknya tersendiri dapat dikembangkan secara lebih intensif, yakni dengan mempersiapkan dan memperbaiki kualitas objek dan atraksi yang ada dengan tetap menggali potensi wisata yang dimiliki, melakukan perencanaan, dan pengelolaan pembangunan objek wisata yang lebih baik, sehingga mendapatkan hasil yang lebih maksimal. pengembangan dan pengelolaan objek wisata tidak hanya dapat dilakukan oleh satu pihak saja, namun harus adanya sinergitas antara pemangku kebijakan dan 
juga peran serta aktif masyarakat dalam pengembangan desa wisata. selain itu untuk dapat memaksimalkan fungsi desa wisata dengan penguatan sumber daya manusia dari Desa Taro sendiri merupakan hal yang sangat penting untuk diperhatikan. sehingga keberadaan desa wisata jga dapat memberikan manfaat yang maksimal bagi masyarakat di desa taro.

Desa wisata Taro menawarkan pengalaman baru, hidup menyatu dengan alam pedesaan yang masih asri dan juga memiliki nilai budaya dan religi yang kuat, menghirup udara segar, jauh dari polusi dan kebisingan, merasakan dan terlibat dalam aktivitas masyarakat setempat, dalam artian bahwa wisatawan tidak hanya melihat begitu saja keindahan alam, tetapi dapat hidup di dalamnya. Wisatawan dapat merasakan dan menikmati secara utuh alam dan sosial budaya di desa taro. Pengembangan desa wisata merupakan salah satu usaha untuk mengantisipasi bahwa orientasi pilihan wisatawan pada tempat-tempat wisata yang tidak "alami" dan juga "asli" akan mencapai titik jenuh. Cara menggali, memanfaatkan, dan membangun sumber daya lokal yang selama ini kurang mendapat perhatian, serta untuk meningkatkan pendapatan berganda masyarakat desa setempat, serta untuk menyeleksi segmen pasar wisatawan yang berorientasi pada budaya dan peduli lingkungan, sesuai dengan amanat pelaksanaan kegiatan kepariwisataan di provinsi bali yaitu pariwisata budaya yang berkesinambungan.

\section{Permasalahan Mitra}

Permasalahan yang dihadapi mitra (Desa Taro) sesuai yang diuraiakan pada pendahuluan adalah:

1. Salah satu bagian penting dari pengembangan Desa Wisata (Pariwisata Berbasis Masyarakat) tentu saja adalah Masyarakat itu sendiri. Oleh karena itu Pengembangan Sumber Daya Manusia sangatlah vital dalam pengembangan kepariwisataan di desa. Perlu adanya peningkatan sumber daya manusia untuk dapat bersinergi dalam pengembangan desa wisata. penguatan sumber daya manusia sangat di butuhkan untuk dapat memaksimalkan potensi dari desa wisata itu sendiri.

2. Seberapa baik kualitas produk desa wisata yang dimiliki, jika tidak memiliki nilai jual akan sangat sia-sia. Oleh karena itu, pengelola desa wisata dalam hal ini sangat di butuhkan oleh desa taro, Teknik untuk memasarkan sesuai dengan era digital pada masa kini dengan memanfaatkan social media sebagai sarana utama. Desa wisata dan branding sangat di butuhkan untuk membawa desa wisata taro lebih dikenal dan dilirik oleh wisatawan sebagai desa wisata yang memiliki keunikan dengan aya tarik maupun atraksi di Desa Wisata Taro yang berbasis kelestarian ekologi dan menjunjung tinggi nilai-nilai spiritualitas dengan kebudayaan yang sangat kuat.

3. Perlu adanya pemahaman tentang ketersediaan aksesibilitas yang tidak hanya dapat dijangkau oleh wisatawan pada umumnya, namun juga di butuhkan aksesibilitas yg aksibel untuk para wisatawan penyandang diabilitas. untuk dapat mewujudkan pariwisata yang ramah disabilitas. 


\section{Solusi dan Target}

Dari permaslahan yang ditemukan di lokasi solusi yang dapat diberikan terkait permasalahan yang dihadapi mitra dapat dirinci seperti uraian berikut:

a. Dalam permasalahan penguatan sumber daya manusia sebgai salah satu unsur yang sangat penting dalam pengembangan desa wisata dapat dilakukan beberapa hal seperti penyuluhan tentang pengelolaan desa wisata, workshop mengenai peluang-peluang yang bisa digunakan oleh masyarakat desa taro dalam pengembangan desa wisata berbasis masyarakat. sehingga pengembangan desa wisata dapat dicapai secara maksimal karna dapat memanfaatkan sumber daya manusia dan sumber daya alamnya sendiri.

b. Dalam hal pengelolaan desa wisata, banyak hal yang perlu diperhatikan, usaha pengembangan desa wisata tidak akan dapat berjalan dengan maksimal jika perencanaan dan pengelolaan tidak dilaksanakan dengan baik, perlu adanya pemahaman yang Mutahir mengikuti perkembangan zaman dalam hal perencanaan dan pengelolaan desa wisata, hal ini bisa dilakukan dengan mengadakan workshop mengenai perencanaan, cara mengelola Teknik pemasaran yang tepat sehingga pengembangan desa wisata dapat dicapai secara maksimal tanpa menghilanhkan unsur-unsur yang penting yang sudah ada dalam desa wisata itu sendiri

c. Hal yang belum dipahami oleh banyak kalangan dimasyarakat mengenai aksesibiltas yang seharusnya wajib ada disetiap fasilitas yang bersifat public salah satunya adalah aksesibilitas yang aksibel untuk para wisatawan penyandang disabilitas, sehingga pariwisata di desa taro tidak hanya dapat dinikmati oleh kalangan bisa namun seluruh masyarakat tanpa diskriminasi. hal ini dapat dicapai dengan mengadalan sosialisasi berkaitan kewajiban dalam penyediaan fasilitas untuk disabilitas dalam kegiatan kepariwisataan.

\section{Metode Pelaksanaan}

\section{Metode Pendekatan}

Berdasarkan hasil identifikasi masalah yang dilakukan di lapangan, maka metode pendekatan yang dilakukan adalah:

1) Metode Edukasi bertujuan untuk memberikan pemahaman bahwa permasalahan yang dihadapi dan penyampaian solusi serta target capaian.

2) Metode Pelatihan yang ditujukan untuk memberikan keterampilan terhadap penyusunan laporan maupun penggunaan adsword serta pemasaran berbasis digital.

3) Metode Pendampingan yang dilakukan untuk meningkatkan pengetahuan dan memantapkan keterampilan mitra dalam mencapai tujuan atau target capaian program.

4) Metode Evaluasi program dengan tujuan untuk mengevaluasi berbagai tahapan kegiatan sehingga dapat mempebaiki dan menyempurnakan pelaksanaan kegiatan di lapangan. Metode Keberlanjutan program dengan tujuan memantau 
kegiatan di lapangan setelah kegiatan berakhir agar tetap dapat dilanjutkan oleh mitra.

\section{Tahap Persiapan}

Tahapan ini meliputi studi pustaka, pengurusan ijin, observasi permasalahan mitra , penyampaian solusi terhadap mitra, kordinasi dan pembagian tugas tim pelaksana, penetapan lokasi kegiatan pelatihan, koordinasi jadwal kegiatan dengan mitra, penyiapan bahan dan alat yang diperlukan sesuai tahapan kegiatan di lapangan.

\section{Tahap Pelaksanaan Kegiatan}

Berdasarkan solusi yang telah disepakati, maka untuk mengatasi permasalahan yang telah ditetapkan bersama yaitu:

1) Workshop pemetaan potensi desa wisata dalam pengembangan usaha desa wisata berbasis digital marketing di social media, untuk meningkatkan angka kunjungan ditingkat local maupun internasional

2) Pendampingan dan pelatihan melakukan promosi melalui social medi8a dengan membuat konten-konten yang menarik.

3) Sosialisasi mengenai aturan terkait dengan kewajiban sebu7ah tempat wisata dalam penyediaan fasilitas bagi disabilitas

\section{Hasil Pengabdian}

Berdasarkan solusi yang telah disepakati, maka untuk mengatasi permasalahan yang telah ditetapkan bersama yaitu: Workshop dengan mendata potensi desa wisata taro dan membuat skema pengembangan dengan digital marketing dalam menghadapi persaingan usaha wisata, yang diselenggarakan di Desa lokasi mitra serta diikuti oleh seluruh stakeholder yang terkait, apartur desa dan perwakilan warga Pendampingan dan pelatihan mengenai digital marketing di sosial media , pendampingan ini bersifat personal dan terjadwal sehingga dapat dilihat perkembangan dari setiap tahapan pendampingan Sosialisasi mengenai aturan tentang aksesibilitas yang wajib ada untuk disabilitas pada fasilitas umum khususnya pada objek wisata. guna adanya peningkatan dalam kualitas pelaksanaan kegiatan kepariwisataan di Desa Taro.

Kemudian karena antusias dari perangkat desa dan meminta pendampingan lebih lanjut menggenai digital marketing menggunakan sarana media sosial, pendampingan dilanjutkan dengan pelaksanaan webinar yang berfokus pada bagaimana cara memanfaatkan social media sebagai flatform promosi yang terjangkau. Digital Marketing (pemasaran digital) adalah suatu usaha untuk mempromosikan sebuah merek dengan menggunakan media digital yang dapat menjangkau konsumen secara tepat waktu, pribadi. hal ini sangat membantu promosi dari desa wisata dalam kondisi

pandemic seperti pada masa Sekarang, karna promosi dengan gaya lama jangakauannya juga terbatas, namun berbeda halnya jika media sosiial yang digunakan untuk sarana promosi, jangkauan dan daerah sebarab promospun bisa ditentukan sendiri tergantung target market yang akan dituju. 


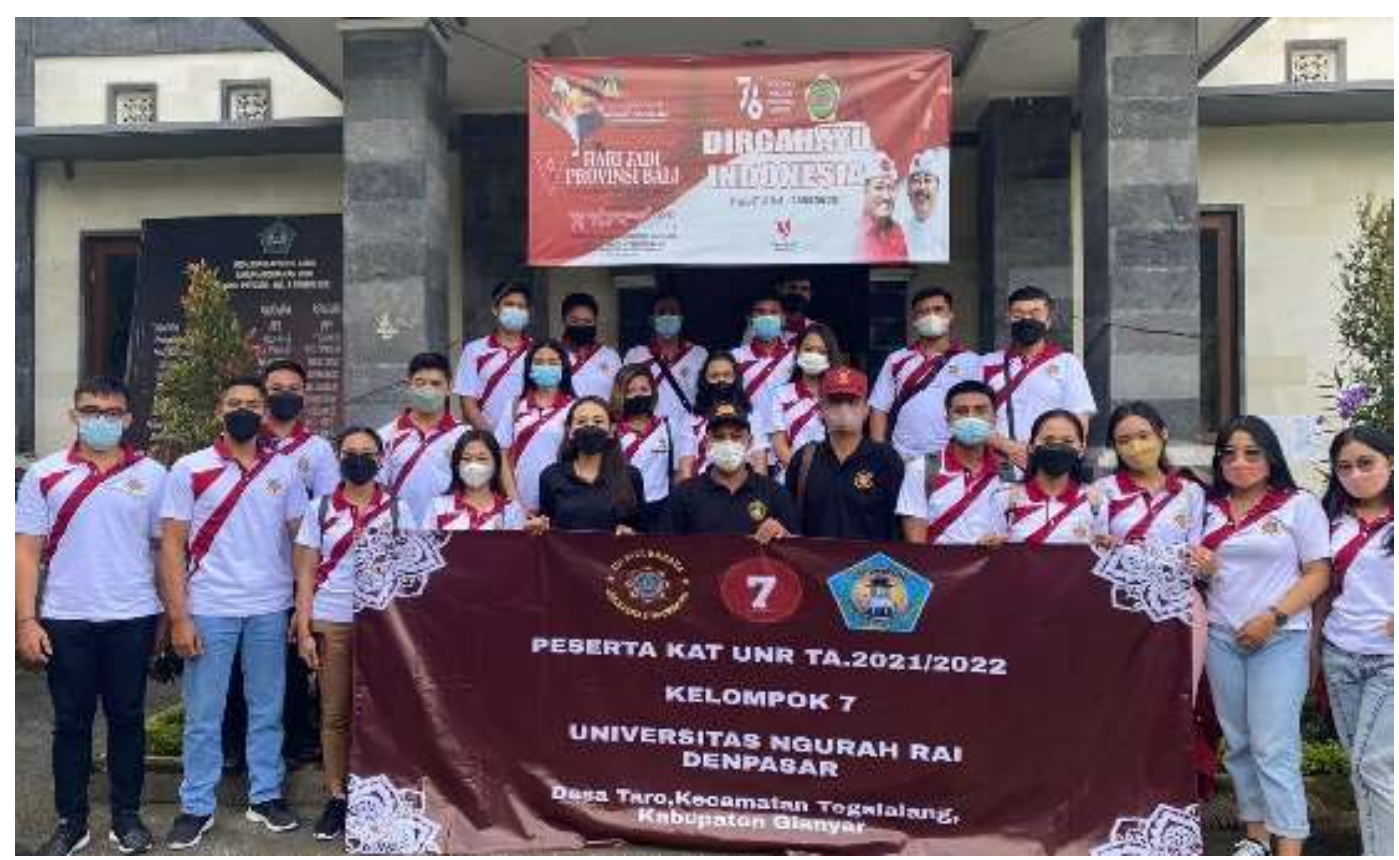

Gambar 1. Kegiatan Pengabdian di Desa Toro desa wisata

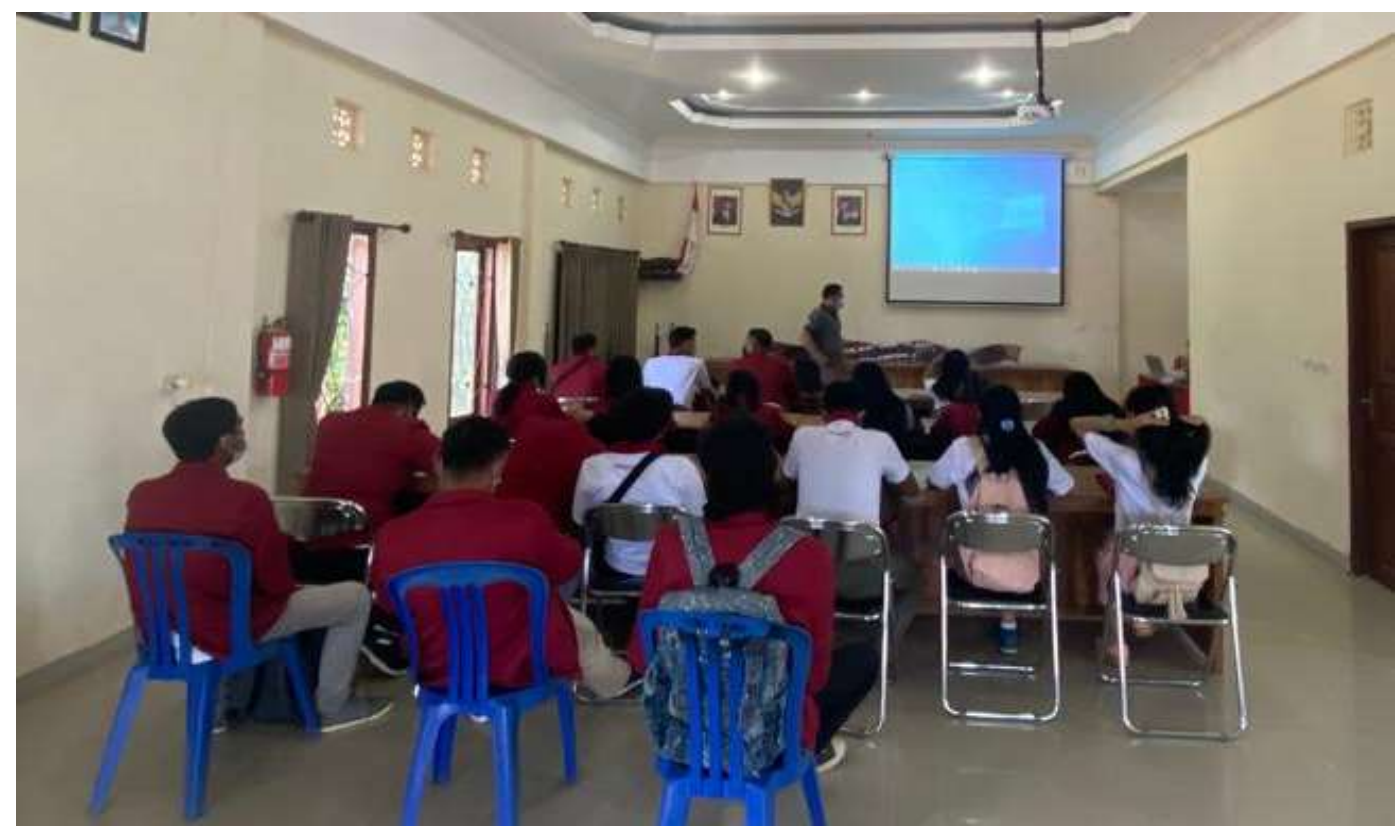

Gambar 2. Workshop dengan mendata potensi desa wisata

Tipe pemasaran digital mencakup banyak teknik dan praktik yang terkandung dalam kategori pemasaran internet. Di dalam Teknik pemasaran berbasis digital marketing, social media adalah sarana yang paling dibutuhkan, karna hampir sebagian masyarakat adalah pengguna aktif media social untuk itu di desa wisata taro sendiri akhirnya kami bantu dengan langkah-langkah penggunaan media social berbayar, sehingga memudahkan target promosi desa wisata jadi lebih tinggi. banyak keuntungan yang kemudian bisa didapat dari promosi dengan menggunakan media social, target jangkauan lebih luas dan akan lebih banyak mendapatkan target wisatawan baru. 


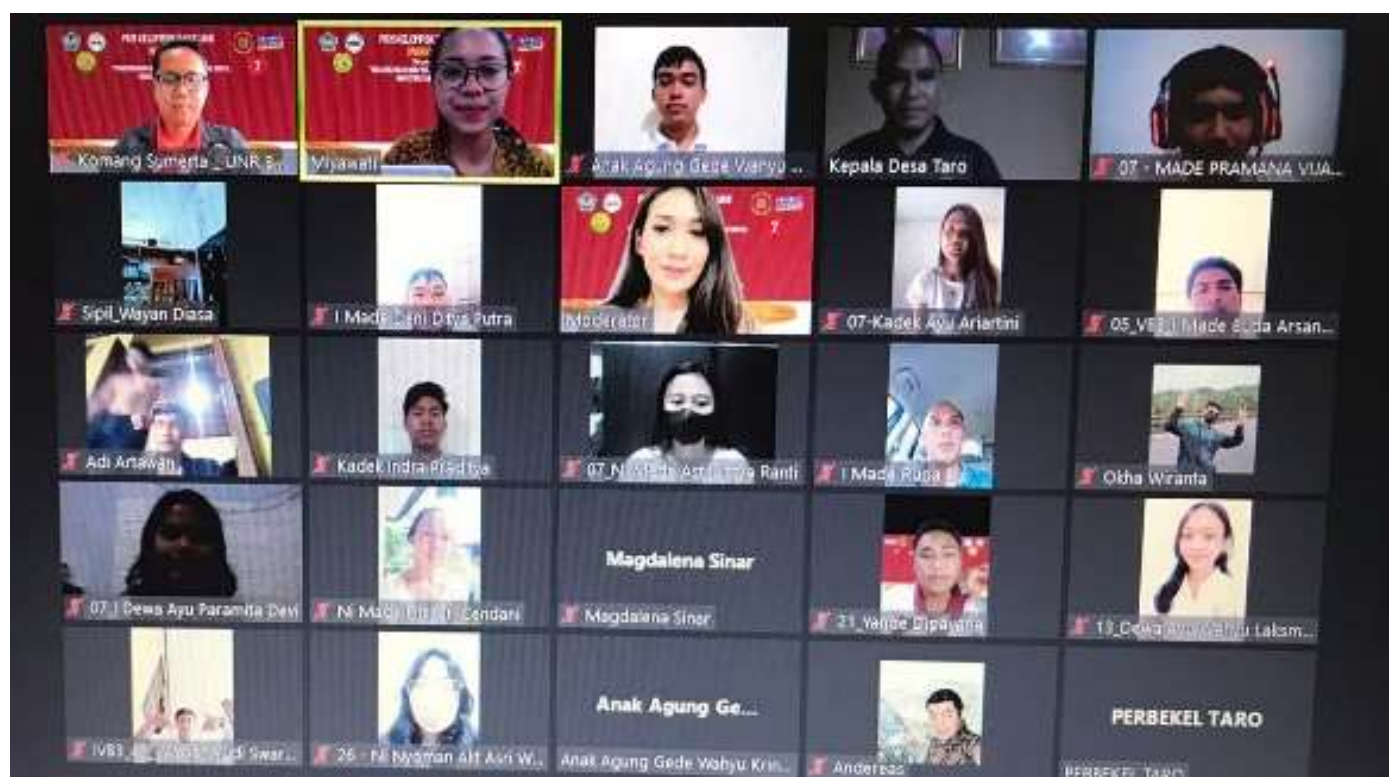

Gmabar 2. Pendampingan dengan secara online dengan zoom

Pendampingan dilanjutkan dengan pembuatan konten digital yang akan digunakan sebagai "rumah digital" untuk desa taro memasarkan segara produk wisata yang sedang dikembangkan.

\section{Kesimpulan}

Desa wisata merupakan salah satu usaha yang memiliki potensi pendapatan yang tinggi di daerah bali, dengan segala potensi yang dimiliki oleh desa wisata taro harusnya dapat menjadi peluang penbingkatan untuk pendapatan desa sendiri, penggunaan digital marketing dlam pemasaran desa wisata merupakan salah satu strategi yang bisa dilaksanakan dan juga merupakan salah satu teknok marketing yang sangat efektif pada masa sekarang, khususnya penggunaan social media untuk media promosi yang murah dan juga lebih luas. Sehingga seluruh potensi dari desa wisata taro dapat dilihat oleh seluruh lapisan masyarakat.

\section{Ucapan Terimakasih}

Terimakasih kami ucapkan kepada seluruh pihak yang telah terlibat dalam menyukseskan kegiatan pengabdian masyarakat ini. Khususnya kami ucapkan terimakasih kepada pimpinan dan warga desa taro yang telah menyediakan waktu dan tempat untuk kami dapat melakukan kegiatan dan program - program pengabdian. Terimakasih kami juga sampaikan kepada Yayasan Jagadhita Denpasar sebagai badan hukum penyelenggaran Universitas Ngurah Rai, kepada Rektor Universitas Ngurah Rai dan Lembaga Penelitian dan Pengabdian Kepada Masyarakat Universitas Ngurah Rai yang telah memberikan pendanaan penuh terhadap kegiatan ini. Terimakasih juga kami ucapkan kepada seluruh sponsor, pihak-pihak lain dan mahasiswa Universitas Ngurah Rai yang terlibat membantu menyukseskan kegiatan ini. 


\section{Referensi}

Nirmala, B. P. W., \& Lavianto, S. (2019). Pemanfaatan Digital Enabler Dalam Transformasi Pemasaran Desa Wisata Berbasis Kerakyatan Di Bali. Jurnal Teknologi Informasi Dan Komputer, 5(1). https://doi.org/10.36002/jutik.v5i1.665

Purnawan, N. L. R., \& Sardiana, I. K. (2018). paket wisata edukasi subak upaya menjaga keberlanjutan potensi pertanian dan pariwisata berbasis budaya di bali. Jurnal Kawistara, 7(3). https://doi.org/10.22146/kawistara.27879

Shobah, N., Pageh, I. M., \& Arta, K. S. (2019). Integrasi Umat Hindu dengan Islam di Desa Tegallinggah, Sukasada Buleleng Bali, sebagai Sumber Pembelajaran Sejarah. Jurnal Widya Winayata: Jurnal Pendidikan Sejarah, 7(1).

Sudirgayasa, I. G., Surata, I. K., Sudiana, I. M., Maduriana, I. M., \& Gata, I. W. (2021). Potensi Ekowisata Lembu Putih Taro Sebagai Konten dan Media Pembelajaran Biologi Berbasis Kearifan Lokal Hindu Bali. Jurnal Imiah Pendidikan Dan Pembelajaran, 5(2). https://doi.org/10.23887/jipp.v5i2.36424

Sumerta, I. K., \& Rai, A. A. G. (2021). Pemetaan potensi usaha desa dan penerapan " adwords " sebagai solusi menghadapi persaingan usaha pada BUMDes Bhuana Amertha Sari Desa Tampaksiring , Gianyar . 1(1), 77-89. https://doi.org/https://doi.org/10.53088/penamas.v1i2.225

Sumerta, I. K., Widyagoca, I. G. P. A., Adiandari, A. M., \& Herlambang, P. G. D. (2019). Analysis of technology acceptance model (TAM) to use E-money in Bali Province. International Journal of Advanced Trends in Computer Science and Engineering, 8(1. 5 Special Issue). https://doi.org/10.30534/ijatcse/2019/3881.52019

Sumerta, I. K., Widyagoca, I. G. P. A., \& Meryawan, I. W. (2019). Online consumer behavior on using social media on E-commerce, based on the AISAS model approach. Case study; Bukalapak, Tokopedia and Blili.com. International Journal of Advanced Trends in Computer Science and Engineering, 8(1.5 Special Issue). https://doi.org/10.30534/ijatcse/2019/4281.52019

Sutiani, N. W. (2022). Peran Serta Kelompok Sadar Wisata (Pokdarwis) Dalam Pengembangan Desa Wisata di Desa Taro Kecamatan Tegallalang Kabupaten Gianyar. Jurnal Cakrawarti, 04(02).

Wijaya, N. S., Sudarmawan, I. W. E., \& Sukaarnawa, I. G. M. (2021). Community base tourism untuk menunjang pariwisata berkelanjutan di kawasan desa wisata taro, tegallalang, gianyar bali. Jurnal IImiah Hospitality Management, 11(2). https://doi.org/10.22334/jihm.v11i2.181 